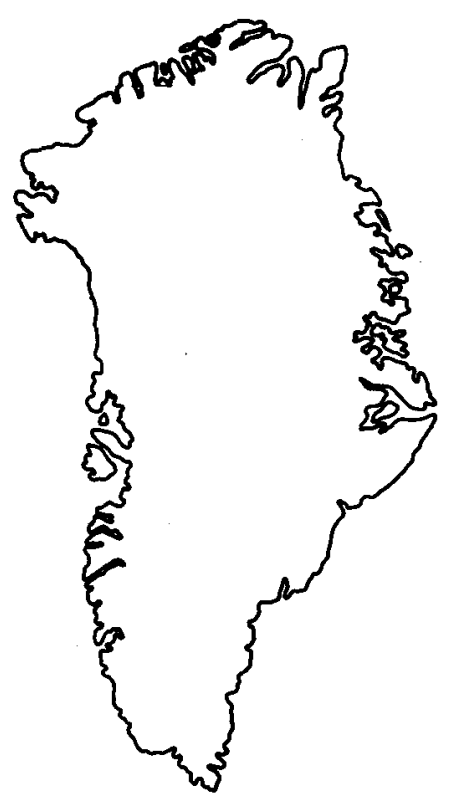

\title{
Cambrian and Ordovician geology of Warming Land and southern Wulff Land, central North Greenland
}

\begin{abstract}
John S. Peel
Fossiliferous Lower Cambrian clastic sediments in Warming Land and southern Wulff Land, central North Greenland, are overlain by about $600 \mathrm{~m}$ of mainly carbonates which have yielded Middle and Late Cambrian trilobites. About $560 \mathrm{~m}$ of succeeding carbonates and subsidiary clastics are tentatively correlated with sequences in Washington Land, to the west, which range in age from Early Ordovician to early Middle Ordovician. The Ordovician sequence is completed by limestones of the Morris Bugt Group, also originally defined from Washington Land.
\end{abstract}

J.S.P., Grønlands Geologiske Undersøgelse, $\emptyset_{\text {ster Voldgade }}$ 10, DK-1350 København K, Danmark.

Geological reconnaissance in Warming Land and southern Wulff Land during June 1979 has provided additional information concerning the Cambrian and Ordovician sequence in central North Greenland. The preliminary notes given here are intended to supplement the descriptions of Hurst \& Peel (1979) which were based on field work during 1978.

Fossiliferous Lower Cambrian clastic sediments have been known from sourthern Wulff Land (fig. 1) for more than a decade, when geologists of Greenarctic Consortium located olenellid trilobites (Dawes, 1976). The clastics were re-examined by Hurst \& Peel (1979) who noted a fauna including Ekwipagetia, Labradoria, Olenellus and Wanneria? from near the top of the unit. The field work during 1979 established the presence of an approximately $600 \mathrm{~m}$ thick sequence of Cambrian carbonates with subsidiary sandstones and siltstones above the Lower Cambrian clastics. Fossils from near the middle of this sequence indicate Middle and Late Cambrian ages and permit a tentative correlation from the Warming Land - Wulff Land sequence to the better known section in Washington Land, to the west.

Some $560 \mathrm{~m}$ of clastic and carbonate sediments occurring above the Cambrian sequence in southern Warming Land and Wulff Land are assigned to the Lower and lower Middle Ordovician. As with the underlying Cambrian strata, a tentative correlation is established with Washington Land. Overlying Middle and Upper Ordovician and Silurian strata in southern Wulff Land have been described by Hurst \& Peel (1979) and will not be further discussed here.

Correlation between the currently described Cambrian and Ordovician sequence and strata occurring in Peary Land, to the east, is tenuous, although several comparisons can be made. 


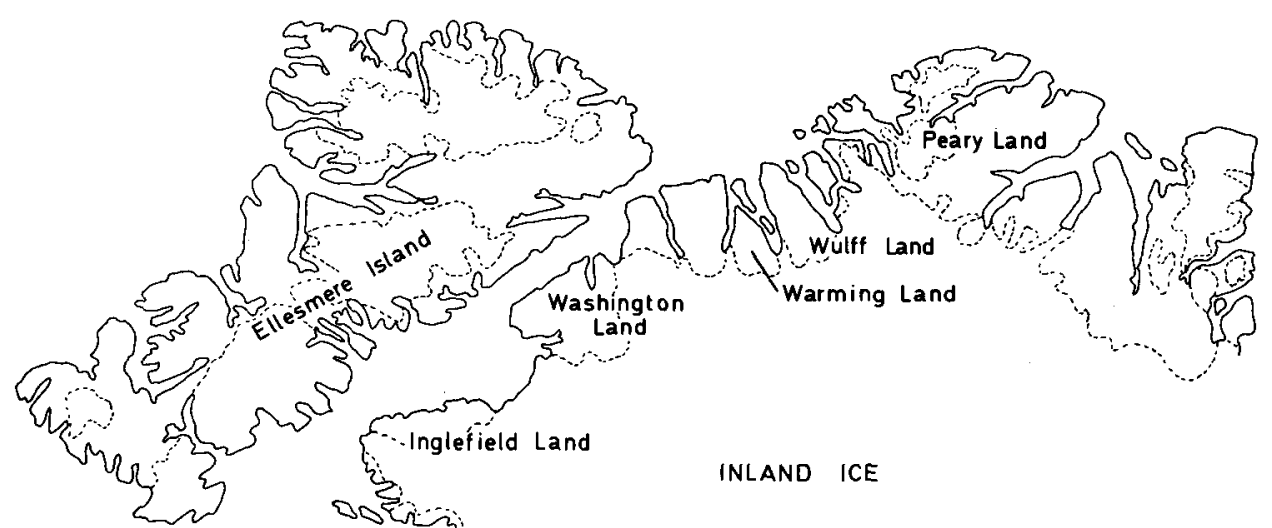

Fig. 1. Locality map, northern Greenland.

\section{Un-named dolomite formation}

Hurst \& Peel (1979) tentatively correlated some tens of metres of thin bedded carbonates and calcareous conglomerates in southern Wulff Land with the Portfjeld Formation of Peary Land, which is now known to be of Early Cambrian age (Peel, 1980). The formation rests on the crystalline basement in south-eastern Wulff Land but has not yielded fossils in this area.

\section{Buen Formation}

A thick (550-700 m) sequence of sandstones and overlying black shales, siltstones and thin sandstones was described from southern Wulff Land by Hurst \& Peel (1979) and correlated with the Buen Formation of Peary Land (Jepsen, 1971). A thin limestone near the top of the formation (fig. 2, $\mathrm{F}_{1}$ ) yielded the Early Cambrian fossils noted above. Equivalent clastics in Washington Land have been given the name Humboldt formation (Peel, 1978; Jepsen \& Dueholm, 1978).

\section{Undifferentiated Cambrian carbonate unit}

This approximately $600 \mathrm{~m}$ thick sequence is largely composed of various types of dolomite, with subsidiary limestones, siltstones and sandstones. Subdivision into several formations is undoubtedly possible. The sequence resembles the Cambrian section known from Washington Land (Henriksen \& Peel, 1976). The lower $100 \mathrm{~m}$ of reddish weathering, cliff-forming dolomites are reminiscent of the Kastrup Elv formation of Washington Land of Early to Middle Cambrian age. The overlying $300-350 \mathrm{~m}$ of the sequence include a variety of relatively thin dolomite units which range in lithology from pale, porcelainous dolomites to dark, sugary, recrystallised dolomites. Greenish siltstones and grey limestones occur near the top of this interval. No immediate correlation with Washington Land is evident, although similar dolomites occur in the upper part of the Kastrup Elv formation. 

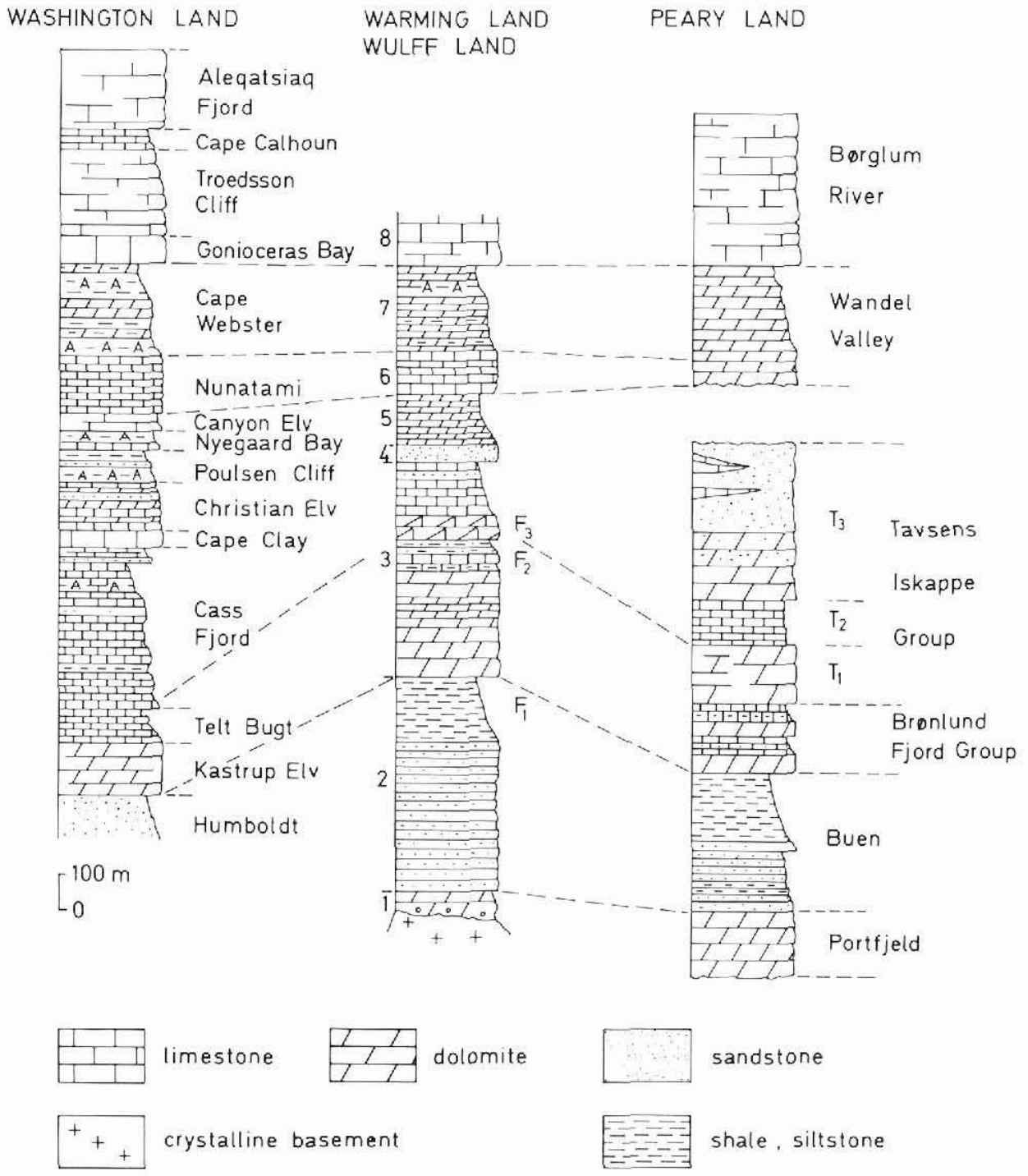

Fig. 2. Cambrian and Ordovician geological profiles in Warming Land and southern Wulff Land, compared to Washington Land and Peary Land. Geological names refer to formations unless otherwise stated; $\mathrm{T}_{1}-\mathrm{T}_{3}$ are un-named formations of the Tavsens Iskappe Group recognised by Ineson \& Peel (1980). $F_{1}-F_{3}$ are fossiliferous horizons discussed in the text and locate Early, Middle and Late Cambrian faunas, respectively. 1, un-named dolomite formation; 2, Buen Formation; 3, undifferentiated Cambrian carbonate unit; 4 , white marker sandstone; 5 , recessive dolomite unit; 6 , cliff-forming limestone and dolomite unit; 7, Cape Webster Formation; 8, Morris Bugt Group (Gonioceras Bay, Troedsson Cliff, Cape Calhoun and Aleqatsiaq Fjord Formations). A, anhydrite. 
The uppermost $200-250 \mathrm{~m}$ of this unit are principally composed of grey weathering, thinly bedded limestones and dolomites with thin beds of white, cross-bedded and laminated sandstone becoming conspicuous at the top. The strata are lithologically similar to parts of the Cass Fjord Formation of Washington Land (Henriksen \& Peel, 1976).

Faunas from this undifferentiated Cambrian unit confirm the lithological correlations suggested above. Trilobite faunas, determined by A. R. Palmer (Geological Society of America), fall into two groups. Several collections from near the middle of the sequence (fig. $2, F_{2}$ ) indicate a late Middle Cambrian age, probably the Bolaspidella zone. Faunas of similar age have also been recognised by Palmer (written communication) in the lowermost beds of the Cass Fjord Formation of Washington Land. Higher collections (fig. 2, F3) contain Terranovella of early Late Cambrian (Middle Dresbachian) age, also known from the lower Cass Fjord Formation in Washington Land.

It has not been possible to make a lithological correlation of the undifferentiated Cambrian carbonate unit from Warming Land and Wulff Land to Peary Land, in the east (Ineson \& Peel, 1980). However, a tentative biostratigraphic correlation is possible since Palmer \& Peel (1979) have identified the Middle Cambrian - Late Cambrian boundary near the base of formation $\mathrm{T}_{2}$ of the Tavsens Iskappe Group (Ineson \& Peel, 1980).

\section{White marker sandstone}

The alternation of limestones, dolomites and thin sandstone beds in the upper part of the undifferentiated Cambrian carbonate unit, discussed above, is succeeded abruptly by a $40 \mathrm{~m}$ thick unit of mainly parallel bedded, white, medium grained sandstone. The sandstone unit contains thin horizons of dark, bioturbated sandstone and forms a prominent marker horizon throughout the area. In Washington Land, similar sandstones of Early Ordovician age occur in the Cass Fjord, Christian Elv and Poulsen Cliff Formations (Henriksen \& Peel, 1976), but no precise correlation is yet established between any of these sandstones and the Warming Land - Wulff Land unit.

The upper beds of formation $\mathrm{T}_{3}$ of the Tavsens Iskappe Group of western Peary Land are also typically white sandstones (Ineson \& Peel, 1980). Correlation between these two areas could indicate that the white marker sandstone unit is of Late Cambrian or earliest Ordovician age, but does not further resolve the correlation to Washington Land.

\section{Recessive dolomite unit}

About $150 \mathrm{~m}$ of an alternation of pale grey, laminated dolomites and dark brown, mottled dolomites overlie the white marker sandstone. A massive, very dark brown weathering basal bed of dolomite contains digitate stromatolites and forms a marked dark cap, $5 \mathrm{~m}$ in thickness, to the underlying white sandstones. Weathering colours of this generally recessive unit vary from dark brown near the base to grey and yellowish brown near the top.

The age of the recessive dolomite unit is not known with certainty, but it is most probably Ordovician. Correlation of the overlying cliff-forming unit with the Nunatami Formation in Washington Land (fig. 2) suggests that the recessive dolomites may be equivalent to all or part of the Cape Clay Formation - Nyegaard Bay Formation sequence. Strata of this age are generally absent from southern Peary Land. 


\section{Cliff-forming limestone and dolomite unit}

Lithologically, this $130 \mathrm{~m}$ thick unit of dark weathering limestones and dolomites closely resembles the underlying recessive unit. Mottled and laminated carbonates are characteristic, with scattered cherts in the lower $40 \mathrm{~m}$. Darker, rather massively weathering beds occur near base, middle and top of the unit, while intervening strata are more thinly bedded and weather pale yellowish-brown.

Scattered cephalopods and gastropods indicate an Ordovician age. The unit is correlated with the Nunatami Formation of Washington Land (fig. 2) in view of its similar erosional characteristics and its stratigraphic position in both areas below the Cape Webster Formation. Peel \& Yochelson (1979) have correlated the Nunatami Formation with the lower part of the Wandel Valley Formation of Peary Land on the basis of the common occurrence of Ceratopea unguis.

\section{Cape Webster Formation}

This pale grey weathering, anhydritic, recessive unit is about $240 \mathrm{~m}$ thick and can be readily referred to the Cape Webster Formation of Washington Land. The formation is approximately equivalent to the upper member of the Wandel Valley Formation of Peary Land (Christie \& Peel, 1977), although anydritic beds have not been recorded from Peary Land. However, the similarity between the two formations is emphasised by the fact that Hurst \& Peel (1979) referred the strata in southern Wulff Land to the Wandel Valley Formation, after a cursory examination.

\section{Morris Bugt Group}

The cliff-forming Ordovician-Silurian limestones of the Morris Bugt Group (Peel \& Hurst, 1980) form a conspicuous mapping horizon across southern Warming Land and southern Wulff Land, above the recessive strata of the underlying Cape Webster Formation. The Gonioceras Bay, Troedsson Cliff, Cape Calhoun and Aleqatsiaq Fjord Formations, which make up the group in central North Greenland as well as in Washington Land, have been discussed by Hurst \& Peel (1979).

\section{References}

Christie, R. L. \& Peel, J. S. 1977: Cambrian-Silurian stratigraphy of Børglum Elv, Peary Land, eastern North Greenland. Rapp. Grønlands geol. Unders. 82, 48 pp.

Dawes, P. R. 1976: Precambrian to Tertiary of northern Greenland. In Escher, A. \& Watt, W. S. (edit.) Geology of Greenland, 248-303. Copenhagen: Geol. Surv. Greenland.

Henriksen, N. \& Peel, J. S. 1976: Cambrian-Early Ordovician stratigraphy in south-western Washington Land, western North Greenland. Rapp. Grønlands geol. Unders. 80, 17-23.

Hurst, J. M. \& Peel, J. S. 1979: Late Proterozoic(?) to Silurian stratigraphy of southern Wulff Land, North Greenland. Rapp. Grønlands geol. Unders. 91, 37-56.

Ineson, J. R. \& Peel, J. S. 1980: Cambrian stratigraphy in Peary Land, eastern North Greenland. Rapp. Grønlands geol. Unders. 99, 33-42. 
Jepsen, H. F. 1971: The Precambrian, Eocambrian, and early Palaeozoic stratigraphy of the Jørgen Brønlund Fjord area, Peary Land, North Greenland. Bull. Grønlands geol. Unders. 96 (also Meddr Grønland 192,2), $42 \mathrm{pp}$.

Jepsen, H. F. \& Dueholm, K. S. 1978: Computer supported geological photo-interpretation. Rapp. Grønlands geol. Unders. 90, 146-150.

Palmer, A. R. \& Peel, J. S. 1979: New Cambrian faunas from Peary Land, eastern North Greenland. Rapp. Grønlands geol. Unders. 91, 29-36.

Peel, J. S. 1978: Geological investigations in Lower Palaeozoic terrain of northern Greenland between $78^{\circ} 30^{\prime} \mathrm{N}$ and $81^{\circ} 30^{\prime} \mathrm{N}$. Rapp. Grønlands geol. Unders. 90, 14-16.

Peel, J. S. 1980: Early Cambrian microfossils from the Portfjeld Formation, Peary Land, eastern North Greenland. Rapp. Grønlands geol. Unders. 100, 15-18.

Peel, J. S. \& Hurst, J. M. 1980: Late Ordovician and early Silurian stratigraphy of Washington Land, western North Greenland. Rapp. Grønlands geol. Unders. 100, 18-24.

Peel, J. S. \& Yochelson, E. L. 1979: Ceratopea (Gastropoda) from Washington Land, western North Greenland. Rapp. Grønlands geol. Unders. 91, 87-91. 